\title{
Pengaruh Retun on Asset, Asset Growth, dan Debt to Equity Ratio terhadap Dividend Payout Ratio
}

(Studi Kasus Pada Perusahaan Sektor Manufaktur yang Terdaftar Di Bursa Efek Indonesia Periode 2012-2016)

\author{
Eka Setiajatnika \& Kandis Iriani \\ Institut Manajemen Koperasi Indonesia
}

\begin{abstract}
The average development of Dividend Payout Ratio in several Manufacturing Sector Companies in Indonesia Stock Exchange period 2012-2016 shows fluctuation. There are several factors related to dividend payout policy such as profit rate, asset expansion rate, and funding requirement. This research uses financial report of 6 (six) manufacturing companies listed in Indonesia Stock Exchange in period 2012-2016 by using comparative descriptive method with quantitative approach and using panel data. The results showed that the Return On Asset and Debt to Equity Ratio partially affect the Dividend Payout Ratio while Asset Growth does not partially affect the Dividend Payout Ratio in the manufacturing sector companies listed on the Indonesia Stock Exchange period 2012-2016. And Return On Asset, Asset Growth, and Debt to Equity Ratio effect simultaneously to Dividend Payout Ratio at manufacturing sector companies listed on Indonesia Stock Exchange period 2012-2016.
\end{abstract}

Keywords: Dividend Payout Ratio, Return on Asset, Asset Growth, Debt to Equity Ratio

\begin{abstract}
Abstrak. Perkembangan rata-rata Dividend Payout Ratio pada beberapa Perusahaan Sektor Manufaktur di Bursa Efek Indonesia periode 2012-2016 menunjukan flukuatif. Terdapat beberapa faktor yang berkaitan dengan kebijakan pembayaran dividen diantaranya tingkat laba, tingkat ekspansi aktiva, dan kebutuhan dana perusahaan. Penelitian ini menggunakan data laporan keuangan 6 (enam) perusahaan sektor manufaktur yang terdaftar di Bursa Efek Indonesia pada periode 2012-2016 dengan menggunakan metode deskriptif komparatif dengan pendekatan kuantitatif dan menggunakan data panel. Hasil penelitian menunjukkan bahwa Return On Asset dan Debt to Equity Ratio berpengaruh secara parsial terhadap Dividend Payout Ratio sedangkan Asset Growth tidak berpengaruh secara parsial terhadap Dividend Payout Ratio pada perusahaan sektor manufaktur yang terdaftar di Bursa Efek Indonesia periode 20122016. Dan Return On Asset, Asset Growth, dan Debt to Equity Ratio berpengaruh secara simultan terhadap Dividend Payout Ratio pada perusahaan sektor manufaktur yang terdaftar di Bursa Efek Indonesia periode 2012-2016.
\end{abstract}

Kata Kunci: Dividend Payout Ratio, Return on Asset, Asset Growth, Debt to Equity Ratio

A. PENDAHULUAN

Menurut Undang-Undang

Republik Indonesia Nomor 8 Tahun 1995 pasal 7 Tentang Pasar Modal menjelaskan Bursa Efek didirikan dengan tujuan menyelenggarakan perdagangan Efek yang teratur, wajar, dan efisien. Sehingga Bursa Efek wajib menyediakan sarana pendukung dan mengawasi kegiatan anggota Bursa Efek. Secara garis besar surat berharga yang diperjual belikan di Bursa Efek atau Stock Exchange salah satunya adalah saham. Menurut Darmadji dan Fakhrudin (2011), Saham (shares) didefinisikan sebagai tanda pernyataan atau pemilikan seseorang atau badan dalam suatu perusahaan atau perseroan terbatas.

Dividen yaitu pembagian keuntungan yang diberikan perusahaan penerbit saham tersebut atas keuntungan yang dihasilkan perusahaan dapat berupa dividen tunai atau dividen saham (Darmadji \& Fakhruddin, 2011). Salah satu indikator yang dapat digunakan untuk mengukur kebijakan dividen adalah rasio pembayaran dividen (Dividend Payout Ratio). Menurut Murhadi (2013:65) “Dividend payout ratio merupakan rasio yang menggambarkan 
besarnya proporsi dividen yang dibagikan terhadap pendapatan bersih perusahaan". Untuk mengetahui perkembangan beberapa perusahaan sektor manufaktur yang terdaftar di Bursa Efek Indonesia dapat dilihat pada gambar 1 di bawah ini.

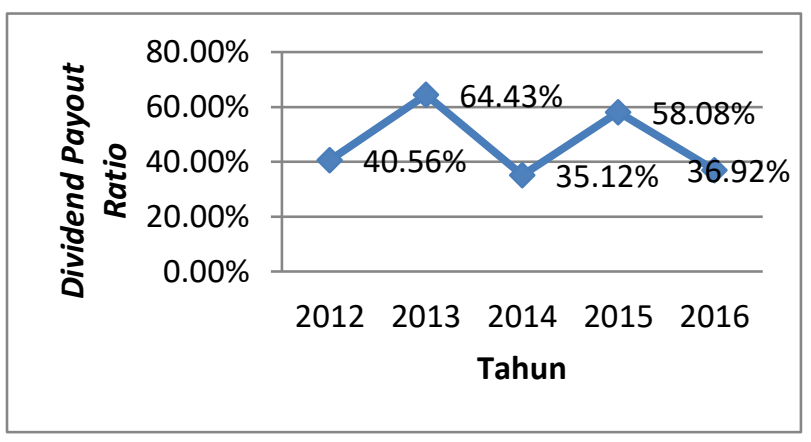

Gambar 1. Perkembangan Rata-rata Dividend Payout Ratio pada Beberapa Perusahaan Sektor Manufaktur di Bursa Efek Indonesia Periode 2012-2016

Pada gambar 1 menunjukan bahwa perkembangan rata-rata Dividend Payout Ratio pada beberapa Perusahaan Sektor Manufaktur di Bursa Efek Indonesia periode 2012 sampai dengan 2016 mengalami perkembangan flukuatif. Perkembangan pada tahun 2013 menunjukan peningkatan tingkat ratarata yang yaitu $64,43 \%$ dari tahun sebelumnya dengan nilai Dividend Payout Ratio pada tahun 2012 sebesar 40,56 \%. Sedangkan pada tahun 2014 mengalami penurunan dengan nilai Dividend Payout Ratio sebesar 35,12. Pada tahun 2016 mengalami penurunan dari sebelumnnya dengan nilai Dividend Payout Ratio yaitu 36,92 \% dan pada tahun 2015 yaitu 58,08\%.

Sartono (2009:292) menyatakan bahwa ada beberapa faktor yang berkaitan dengan kebijakan pembayaran dividen diantaranya tingkat laba, tingkat ekspansi aktiva, dan, kebutuhan dana perusahaan.
Dalam penelitian yang dilakukan oleh Rembulan, M. Nadratuzzzaman, Syafaat (2016) menyimpulkan 'this research conducting many conclusion first the ROA, asset growth, and the Dividend Payout Ratio in a previous year significantly influence the Dividend Payout Ratio'. Penelitian ini menyimpulkan Return on asset, Asset growth, and the Dividend Payout Ratio berpengaruh terhadap Dividend Payout Ratio. Hal tersebut di dukung oleh penelitian Dwidamita (2016) menyimpulkan bahwa Return On Asset (ROA), dan Debt To Equity Ratio (DER) secara simultan berpengaruh terhadap Dividend payout ratio (DPR).

Berdasarkan uraian yang terdapat pada latar belakang penelitian, maka permasalahan yang akan dibahas dalam penelitian ini dapat dirumuskan yaitu seberapa besar pengaruh Return on Asset, Asset Growth, dan Debt to Equity Ratio terhadap Dividend Payout Ratio. Adapun maksud dan tujuan dalam penelitian ini adalah untuk mengetahui pengaruh Return on Asset, Asset Growth, dan Debt to Equity Ratio terhadap Dividend Payout Ratio.

\section{B. KAJIAN TEORI}

Rahayuningtyas (2014), mengatakan Dividend payout ratio $(D P R)$ merupakan presentase laba yang dibayarkan dalam bentuk dividen. Black's Law Dictionary dalam Irham Fahmi (2012:83) Dividen adalah: "The distribution of current of accumulated earning to shareholders of corporation pro rate based on the number of share owned". Dividen merupakan pembagian keuntungan yang diberikan perusahaan dan berasal dari keuntungan yang dihasilkan perusahaan.

Pengertian return on assets menurut Kasmir (2014:201) yaitu "return on total assets merupakan rasio 
yang menunjukkan hasil (return) atas jumlah aktiva yang digunakan dalam perusahaan". Sleihat (2013: 25), menjelaskan bahwa Return On Asset (ROA) adalah rasio yang menunjukkan seberapa efektif perusahaan beroperasi sehingga menghasilkan keuntungan atau kerugian bagi perusahaan.

Definisi Growth menurut Kasmir (2012:107) adalah "Rasio pertumbuhan (Growth Ratio) merupakan rasio yang menggambarkan kemampuan perusahaan mempertahankan posisi ekonominya di tengah pertumbuhan perekonomian dan sektor usahanya." Dan menurut Irham Fahmi (2011:69) menjelaskan bahwa "Rasio pertumbuhan adalah rasio yang mengukur seberapa besar kemampuan perusahaan dalam mempertahankan posisinya didalam industri dan dalam perkembangan ekonomi secara umum."

Menurut Kasmir (2014:157), menyatakan bahwa Debt to equity ratio merupakan rasio yang digunakan untuk menilai hutang dengan ekuitas. Rasio ini dicari dengan cara membandingkan antara seluruh hutang, termasuk hutang lancar dengan seluruh ekuitas. Rasio ini digunakan untuk mengetahui jumlah dana yang disediakan peminjam (kredior) dengan pemilik perusahaan. Sedangkan menurut Sofyan Syafri Harahap (2010, hal. 303) menyatakan bahwa "rasio ini menggambarkan sampai sejauh mana modal pemilik dapat menutupi utangutang kepada pihak luar". Semakin kecil rasio ini semakin baik.

Atas dasar analisis, kajian teori dan jurnal penelitian, maka pengaruh dari masing-masing variabel dapat digambarkan dalam skema sebagai berikut :

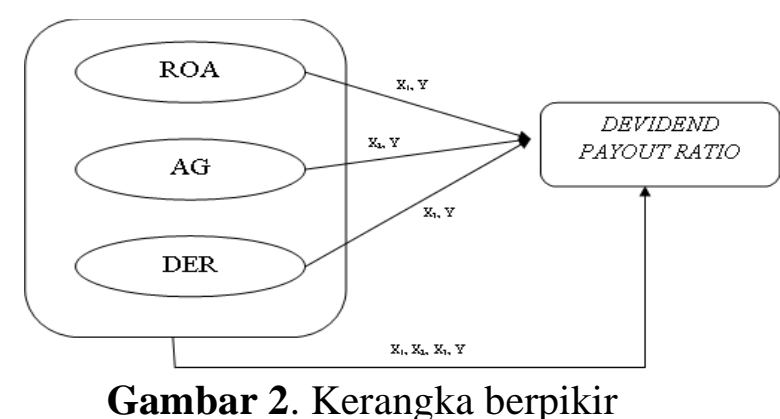

Pada gambar 2 menunjukan bahwa $\mathrm{X}_{1}, \mathrm{Y}$ merupakan pengaruh Return On Asset terhadap Dividend Payout Ratio; $\mathrm{X}_{2}, \quad \mathrm{Y}$ merupakan pengaruh Asset Growth terhadap Dividend Payout Ratio; $\mathrm{X}_{3}, \quad \mathrm{Y}$ merupakan pengaruh Debt to Equity Ratio terhadap Dividend Payout Ratio; dan $\mathrm{X}_{1}, \mathrm{X}_{2}, \mathrm{X}_{3}, \mathrm{Y}$ merupakan pengaruh pengaruh Return On Asset, Debt to Equity Ratio, Debt to Equity Ratio terhadap Dividend Payout Ratio.

Menurut Sartono (2009:292) menyatakan bahwa ada beberapa faktor yang berkaitan dengan kebijakan pembayaran dividen yaitu profitabilitas atau tingkat laba diproksikan dengan ROA Hal tersebut didukung oleh jurnal Dwidarnita Parera (2016), yang menyimpulkan bahwa Return On Asset mempengaruhi Dividend Payout Ratio, tingkat ekspansi aktiva diproksikan dengan Asset Growth hal tersebut didukung oleh jurnal Winda (2014), yang menyimpulkan bahwa Asset Growth mempengaruhi Dividend Payout Ratio, dan kebutuhan dana perusahaan diproksikan dengan Debt to Equity Ratio hal tersebut didukung oleh jurnal Dwidarnita Parera (2016), yang menyimpulkan bahwa Debt to Equity Ratio mempengaruhi Dividend Payout Ratio.

\section{METODE PENELITIAN}

Objek Penelitian ini adalah Laporan Keuangan tahun 2012-2016 dari perusahaan sektor manufaktur 
yang terdaftar di Bursa Efek Indonesia. Indonesia yang terdiri dari 4 (tiga ) variabel : Return On Asset, Variabel $\left(\mathrm{X}_{1}\right)$ sebagai variabel independen, Asset Growth, Variabel $\left(\mathrm{X}_{2}\right)$ sebagai variabel independen, Debt to Equity Ratio, Variabel $\left(\mathrm{X}_{3}\right)$ sebagai variabel independen, Dividend Payout Ratio, variabel (Y) sebagai variabel dependen.

Metode yang digunakan dalam penelitian ini adalah metode deskriptif komparatif dengan pendekatan kuantitatif dan menggunakan data panel. Adapun data yang diperlukan dalam penelitian ini adalah data sekunder. Data sekunder diperoleh oleh peneliti dari Laporan publikasi perusahaan sektor manufaktur pada tahun 2012 sampai dengan tahun 2016 di Bursa Efek Indonesia yang berkaitan dengan permasalahan yang diteliti. Perusahaan sektor manufaktur yang terdaftar dalam Bursa Efek Indonesia diantaranya: Astra International Tbk., Astra Otoparts Tbk., Sepatu Bata Tbk.,
Multi Bintang Indonesia Tbk., Selamat Sempurna Tbk., dan Surya Toto Indonesia Tbk. Teknik pengambilan sampel yang digunakan penulis yaitu dengan menggunakan teknik purposive sampling. Adapun daftar sampel penelitian yang diambil yaitu enam perusahaan sektor manufaktur yang terdaftar di Bursa Efek Indonesia yang disajikan pada tabel 1 berikut :

Tabel 1

Daftar Sampel Penelitian

\begin{tabular}{|c|l|l|}
\hline No & Kode & \multicolumn{1}{|c|}{ Perusahaan } \\
\hline 1 & ASII & Astra International Tbk. \\
\hline 2 & AUTO & Astra Otoparts Tbk. \\
\hline 3 & BATA & Sepatu Bata Tbk. \\
\hline 4 & MLBI & $\begin{array}{l}\text { Multi Bintang Indonesia } \\
\text { Tbk. }\end{array}$ \\
\hline 5 & SMSM & Selamat Sempurna Tbk. \\
\hline 6 & TOTO & $\begin{array}{l}\text { Surya Toto Indonesia } \\
\text { Tbk. }\end{array}$ \\
\hline
\end{tabular}

Sumber : Bursa Efek Indonesia (Data yang diolah) 
Tabel 2

Operasionalisasi Variabel Penelitian

\begin{tabular}{|c|c|c|c|c|}
\hline Variabel & Konsep & Sub variabel & Indikator & $\begin{array}{l}\text { Skala } \\
\text { Pengukuran }\end{array}$ \\
\hline \multirow{2}{*}{$\begin{array}{l}\text { Dividen Payout } \\
\text { Ratio }\end{array}$} & \multirow{2}{*}{$\begin{array}{l}\text { Rahayuningtyas (2014): } \\
\begin{array}{ll}\text { Dividend payout ratio } \\
\text { (DPR) merupakan } \\
\text { presentase laba yang } \\
\text { dibayarkan } & \text { dalam } \\
\text { bentuk dividen }\end{array}\end{array}$} & $\begin{array}{l}\text { Dividen tunai per lembar } \\
\text { saham }\end{array}$ & $\begin{array}{lcr}\text { Total } & \text { Dividen } & \text { yang } \\
\text { dibagikan } & \text { dan } & \text { Jumlah } \\
\text { lembar } & \text { saham } & \text { yang } \\
\text { beredar } & & \\
\end{array}$ & \multirow[t]{2}{*}{ Rasio } \\
\hline & & $\begin{array}{l}\text { Laba bersih per lembar } \\
\text { saham }\end{array}$ & $\begin{array}{l}\text { Laba bersih setelah pajak } \\
\text { danJumlah lembar saham } \\
\text { yang beredar }\end{array}$ & \\
\hline \multirow[b]{2}{*}{$\begin{array}{l}\text { Return } \\
\text { Asset }\end{array}$} & \multirow{2}{*}{$\begin{array}{l}\text { Kasmir (2014:201): } \\
\text { "return on total assets } \\
\text { merupakan rasio yang } \\
\text { menunjukkan hasil } \\
\text { (return) atas jumlah } \\
\text { aktiva yang digunakan } \\
\text { dalam perusahaan". }\end{array}$} & Laba Bersih & $\begin{array}{l}\text { Pendapatan, Biaya } \\
\text { Operasional, Biaya Bunga } \\
\text { dan Biaya Pajak }\end{array}$ & \multirow[b]{2}{*}{ Rasio } \\
\hline & & Total Asset & $\begin{array}{l}\text { Aktiva Lancar: } \\
\text { (Kas, piutang, Persediaan } \\
\text { dan Investasi } \\
\text { Aktiva Tetap: Aktiva } \\
\text { lainnya }\end{array}$ & \\
\hline \multirow[b]{2}{*}{ Asset Growth } & \multirow{2}{*}{\begin{tabular}{l} 
Menurut Irham Fahmi \\
(2011:69) \\
"Rasio pertumbuhan \\
adalah rasio yang \\
mengukur reberapa \\
besar kemampuan \\
perusahaan dalam \\
mempertahankan \\
posisinya didalam \\
industri dan dalam \\
perkembangan ekonomi \\
\multicolumn{2}{l}{ secara umum." }
\end{tabular}} & Total Asset & $\begin{array}{l}\text { Aktiva Lancar: Kas, } \\
\text { Piutang, Persediaan, dan } \\
\text { Investasi } \\
\text { Aktiva Tetap } \\
\text { Aktiva lainnya } \\
\end{array}$ & \multirow[b]{2}{*}{ Rasio } \\
\hline & & $\begin{array}{l}\text { Total Asset } \\
\text { sebelumnya }\end{array}$ & $\begin{array}{l}\text { Total Asset tahun } \\
\text { sebelumnya } \\
\text { Aktiva Lancar }(\mathrm{t}-1) \\
\text {-Kas }(\mathrm{t}-1) \\
\text {-Piutang }(\mathrm{t}-1) \\
\text {-Persediaan }(\mathrm{t}-1) \\
\text {-Investasi }_{(\mathrm{t}-1)} \\
\text { Aktiva Tetap }_{(\mathrm{t}-1)}\end{array}$ & \\
\hline \multirow[b]{2}{*}{$\begin{array}{l}\text { Debt to Equity } \\
\text { Ratio }\end{array}$} & \multirow[b]{2}{*}{$\begin{array}{l}\text { Menurut Kasmir } \\
(2014: 157),: \\
\text { Debt to equity ratio } \\
\text { merupakan rasio yang } \\
\text { digunakan untuk } \\
\text { menilai hutang dengan } \\
\text { ekuitas. Rasio ini dicari } \\
\text { dengan rara } \\
\text { membandingkan antara } \\
\text { seluruh hutang, } \\
\text { termasuk hutang lancar } \\
\text { dengan seluruh ekuitas. } \\
\text { Rasio ini digunakan } \\
\text { untuk mengetahui } \\
\text { jumlah dana yang } \\
\text { disediakan peminjam } \\
\text { (kredior) dengan } \\
\text { pemilik perusahaan. }\end{array}$} & Total Hutang & $\begin{array}{ll}\text { - } & \text { hutang lancar } \\
\text { - } & \text { hutang jangka } \\
\text { panjang } & \end{array}$ & \multirow[b]{2}{*}{ Rasio } \\
\hline & & Modal & $\begin{array}{ll}- & \text { Modal sendiri } \\
\text { - } & \text { Modal disetor } \\
\text { - } & \text { Laba ditahan }\end{array}$ & \\
\hline
\end{tabular}


Dalam penelitian ini digunakan beberapa pengujian data diantaranya: uji normalitas, Uji Multikolinearitas, Uji Heteroskedastisitas, Uji Autokorelasi dengan analisis regresi panel dengan menggunakan eviews 9, estimasi data panel umumnya terdapat tiga metode perhitungan, yaitu metode Commont Effect, metode Fixed Effect), dan metode Random Effect. Dalam penelitian ini penulis akan memilih metode berdasarkan hasil analisis data dari uji chow-tes dan uji hausman sehingga metode tersebut layak untuk digunakan. Untuk mengetahui ada tidaknya pengaruh signifikan semua variabel independen yang digunakan secara bersama-sama (simultan) terhadap variabel dependen dilakukan dengan mengukur tingkat signifikansi $\mathrm{F}$ hitung, dimana apabila tingkat signifikansi tersebut lebih kecil dari $\alpha$ maka berarti terdapat pengaruh yang signifikan dari variabel independen secara simultan terhadap variabel dependen. Uji ini digunakan untuk menguji keberartian pengaruh dari seluruh variabel independen secara bersama-sama terhadap variabel dependen.

Untuk mengetahui ada tidaknya pengaruh yang signifikan dari masingmasing variabel independen terhadap variabel dependen digunakan uji t. Dalam menentukan nilai $t$ statistik tabel digunakan tingkat signifikansi $5 \%$ dengan derajat kebebasan $\mathrm{df}=(\mathrm{n}-$ $\mathrm{k}-1$ ), dimana $\mathrm{n}$ adalah jumlah observasi dan $\mathrm{k}$ adalah jumlah variabel. Penelitian ini menggunakan regresi berganda, maka masing-masing variabel independen return on assets (ROA), asset growth, dan debt to equity ratio terhadap Dividen Payout Ratio, yang dinyatakan dengan adjusted $\mathrm{R}^{2}$ untuk menyatakan koefisien determinasi atau seberapa besar pengaruh variabel return on asset, asset growth dan debt to equity ratio secara simultan terhadap variabel dividend payout ratio (Y), sedangkan $\mathrm{r}^{2}$ untuk menyatakan koefisien determinasi parsial variabel independen terhadap variabel dependen.

\section{HASIL PENELITIAN DAN PEMBAHASAN}

\section{Statistik Deskriptif Penelitian}

Tabel 3

Analisis Statistik Deskriptif

\begin{tabular}{lcccc}
\hline \hline & DPR & ROA & AG & DER \\
\hline \hline Mean & 0.486354 & 0.149629 & 0.131504 & 0.900833 \\
Median & 0.442300 & 0.098950 & 0.134300 & 0.670000 \\
Maximum & 1.459200 & 0.657200 & 0.546900 & 3.560000 \\
Minimum & 0.006800 & 0.022500 & -0.058400 & 0.320000 \\
Std. Dev. & 0.330636 & 0.138716 & 0.141726 & 0.800467 \\
Observations & 24 & 24 & 24 & 24
\end{tabular}

Sumber : Output Eviews 9

Berdasarkan Tabel 3 telah ditentukan nilai mean, median, maximum, minimum dan standard deviation untuk masing-masing variabel penelitian dari 24 observasi pada 6 perusahaan dalam 4 periode dengan variabel sebagai berikut ini :

\section{Devidend Payout Ratio}

Pada variabel dependent ini menunjukan output sebagaimana pada tabel, yaitu :

1. Nilai rata-rata Devidend Payout Ratio sebesar 0,486354;

2. Nilai tengah Devidend Payout Ratio sebesar 0,442300;

3. Nilai maksimal Devidend Payout Ratio sebesar 1,459200;

4. Nilai minimum Devidend Payout Ratio sebesar 0,006800; dan

5. Nilai standar deviasi Devidend Payout Ratio sebesar 0,330636. 


\section{Return On Asset}

Pada variabel independent ini menunjukan output sebagaimana pada tabel, yaitu :

1. Nilai rata-rata Return On Asset sebesar 0,149629;

2. Nilai tengah Return On Asset sebesar 0,098950;

3. Nilai maksimal Return On Asset sebesar 0,657200;

4. Nilai minimum Return On Asset sebesar 0,022500; dan

5. Nilai standar deviasi Return On Asset sebesar 0,138716.

\section{Asset Growth}

Pada variabel independent ini menunjukan output sebagaimana pada tabel, yaitu :

1. Nilai rata-rata Asset Growth sebesar 0,131504;

2. Nilai tengah Asset Growth sebesar 0,134300;

3. Nilai maksimal Asset Growth sebesar 0,546900;

4. Nilai minimum Asset Growth sebesar -0,058400; dan

5. Nilai standar deviasi Asset Growth sebesar 0,141726.

\section{Debt to Equity Ratio}

Pada variabel independent ini menunjukkan output sebagaimana pada tabel, yaitu :

1. Nilai rata-rata Debt to Equity Ratio sebesar 0,900833;

2. Nilai tengah Debt to Equity Ratio sebesar 0,67;

3. Nilai maksimal Debt to Equity Ratio sebesar 3,56;

4. Nilai minimum Debt to Equity Ratio sebesar 0,32; dan

5. Nilai standar deviasi Debt to Equity Ratio sebesar 0,800467.

Selanjutnya, hasil analisis deskriptif komparatif berdasarkan masing masing variabel independent :

\section{Tabel 4}

Perkembangan Return On Asset pada Perusahaan Sektor Manufaktur di Bursa Efek Indonesia Periode 2012-2016

\begin{tabular}{|c|l|l|l|l|l|l|l|}
\hline \multirow{2}{*}{ No } & Perusahaan & \multicolumn{2}{|l|}{$\%$} & \multicolumn{2}{|l|}{$\begin{array}{l}\text { Rata- } \\
\text { rata }\end{array}$} \\
\cline { 3 - 8 } & & $\mathbf{2 0 1 2}$ & $\mathbf{2 0 1 3}$ & $\mathbf{2 0 1 4}$ & $\mathbf{2 0 1 5}$ & $\mathbf{2 0 1 6}$ & \\
\hline 1 & $\begin{array}{l}\text { Astra } \\
\text { International } \\
\text { Tbk. }\end{array}$ & 12,48 & 10,42 & 9,37 & 6,36 & 6,99 & 9,12 \\
\hline 2 & $\begin{array}{l}\text { Astra } \\
\text { Otoparts } \\
\text { Tbk. }\end{array}$ & 12,79 & 8,39 & 6,65 & 2,25 & 2,35 & 6,49 \\
\hline 3 & $\begin{array}{l}\text { Sepatu Bata } \\
\text { Tbk. }\end{array}$ & 12,08 & 6,52 & 9,13 & 16,23 & 3,66 & 9,52 \\
\hline 4 & $\begin{array}{l}\text { Multi } \\
\text { Bintang } \\
\text { Indonesia } \\
\text { Tbk. }\end{array}$ & 39,36 & 65,72 & 35,63 & 23,65 & 28,60 & 38,59 \\
\hline 5 & $\begin{array}{l}\text { Selamat } \\
\text { Sempurna } \\
\text { Tbk. }\end{array}$ & 18,63 & 19,88 & 24,09 & 20,78 & 6,25 & 17,93 \\
\hline 6 & $\begin{array}{l}\text { Surya Toto } \\
\text { Indonesia } \\
\text { Tbk. }\end{array}$ & 15,50 & 13,55 & 14,49 & 11,69 & 6,40 & 12,33 \\
\hline
\end{tabular}

Sumber : Data yang diolah dari Laporan Keuangan Publikasi di BEI

Pada tabel menunjukkan terjadi penurunan untuk perusahaan Astra Otopart Tbk. pada tahun 2015 sebesar 0,29\%, Multi Bintang Indonesia Tbk. pada tahun 2015 yaitu sebesar 5,84\% dan Selamat Sempurna Tbk. pada tahun 2016 sebesar 3,21\%.

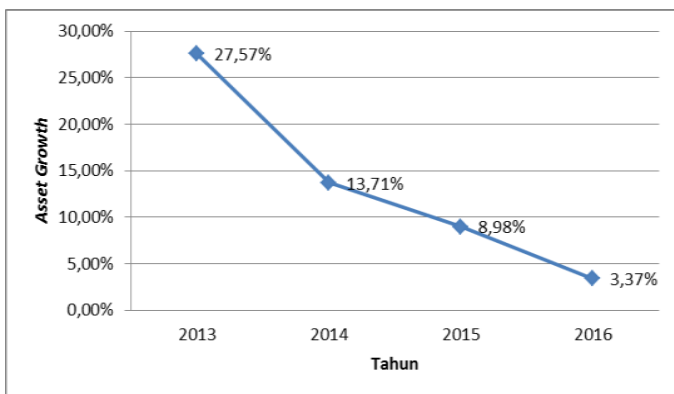

Sumber : Data yang diolah dari Laporan Keuangan Publikasi di BEI

Gambar 3. Perkembangan Rata-rata Return On Asset pada Perusahaan Sektor Manufaktur di Bursa Efek Indonesia Periode 2012-2016

Pada gambar grafik 3 menunjukan bahwa perkembangan rata-rata Asset Growth pada Perusahaan Sektor Manufaktur di Bursa Efek Indonesia periode 2013 sampai dengan 2016 mengalami 
kecenderungan menurun. Pada tahun 2013 sampai dengan 2016 perkembangan rata - rata Asset Growth yaitu sebesar $27,57 \%$; $13,71 \%$; 8,98\%; dan $3,37 \%$. Hal tersebut menunjukan kurang baiknya perkembangan asset ke enam perusahaan sektor manufaktur yang terdaftar di Bursa Efek Indonesia ini.

\section{Asset Growth}

\section{Tabel 5}

Perkembangan Asset Growth pada Perusahaan Sektor Manufaktur di Bursa Efek Indonesia Periode 2013-2016

\begin{tabular}{|c|c|c|c|c|c|c|}
\hline \multirow{2}{*}{ No } & \multirow{2}{*}{ Perusahaan } & \multicolumn{4}{|c|}{ Persentase (\%) } & \multirow{2}{*}{$\begin{array}{l}\text { Rata- } \\
\text { rata }\end{array}$} \\
\hline & & 2013 & 2014 & 2015 & 2016 & \\
\hline 1 & $\begin{array}{l}\text { Astra } \\
\text { International } \\
\text { Tbk. }\end{array}$ & 17,40 & 10,30 & 3,99 & 6,69 & 9,60 \\
\hline 2 & $\begin{array}{l}\text { Astra Otoparts } \\
\text { Tbk. }\end{array}$ & 42,06 & 13,97 & $-0,29$ & 2,79 & 14,63 \\
\hline 3 & $\begin{array}{l}\text { Sepatu Bata } \\
\text { Tbk. }\end{array}$ & 18,56 & 13,84 & 2,63 & 0,70 & 8,93 \\
\hline 4 & $\begin{array}{l}\text { Multi Bintang } \\
\text { Indonesia Tbk. }\end{array}$ & 54,69 & 25,19 & $-5,84$ & 13,02 & 21,77 \\
\hline 5 & $\begin{array}{l}\text { Selamat } \\
\text { Sempurna } \\
\text { Tbk. }\end{array}$ & 18,03 & 2,84 & 26,91 & $-3,21$ & 11,14 \\
\hline 6 & $\begin{array}{ll}\text { Surya } & \text { Toto } \\
\text { Indonesia Tbk. }\end{array}$ & 14,68 & 16,10 & 20,34 & 0,22 & 12,84 \\
\hline
\end{tabular}

Sumber : Data yang diolah dari Laporan Keuangan Publikasi di BEI

Tabel 5 menunjukkan dimana perusahaan Astra International Tbk. untuk nilai rasio DER pada tahun 2012 dan 2013 berada di atas 1,00 yaitu sebesar 1,03 dan 1,02. Selanjutnya untuk nilai rasio DER yang berada di atas 1,00 yaitu Multi Bintang Indonesia Tbk. pada tahun 2012, 2014, 2015, 2016 sebesar 2,49; 3,03; 1,74; dan 3,56 .

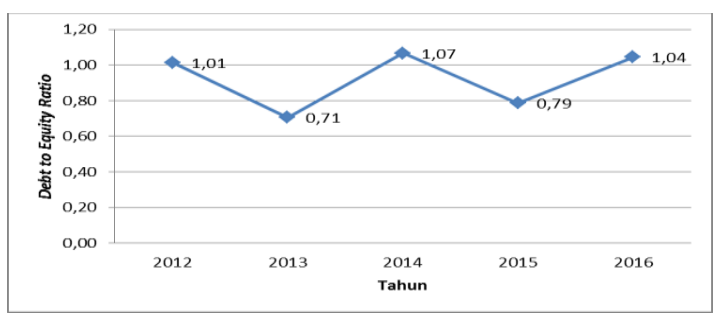

Sumber : Data yang diolah dari Laporan Keuangan Publikasi di BEI
Grafik 4. Perkembangan Rata-rata Asset Growth pada Perusahaan Sektor Manufaktur di Bursa Efek Indonesia Periode 2013-2016

Pada tabel menunjukkan pada tahun 2013 dan tahun 2015 perkembangan rata- rata Debt to Equity Ratio yaitu 0,71 dan 0,79 menandakan saham perusahaan lebih besar dari pinjaman perusahaan dikarenakan berada di bawah angka 1,00. Sedangkan sebaliknya pada tahun 2012, 2014, dan 2016 berada di atas angka 1,00 yaitu sebesar 1,$01 ; 1,07$; dan 1,04 .

\section{Debt to Equity Ratio}

Tabel 6

Perkembangan Debt To Equity Ratio pada Perusahaan Sektor Manufaktur di Bursa Efek Indonesia Periode 20122016

\begin{tabular}{|c|l|c|c|c|c|c|c|}
\hline No & Perusahaan & $\mathbf{2 0 1 2}$ & $\mathbf{2 0 1 3}$ & $\mathbf{2 0 1 4}$ & $\mathbf{2 0 1 5}$ & $\mathbf{2 0 1 6}$ & $\begin{array}{l}\text { Rata- } \\
\text { rata }\end{array}$ \\
\hline 1 & $\begin{array}{l}\text { Astra } \\
\text { International } \\
\text { Tbk. }\end{array}$ & 1,03 & 1,02 & 0,96 & 0,94 & 0,93 & 0,98 \\
\hline 2 & $\begin{array}{l}\text { Astra } \\
\text { Otoparts } \\
\text { Tbk. }\end{array}$ & 0,62 & 0,32 & 0,42 & 0,41 & 0,43 & 0,44 \\
\hline 3 & $\begin{array}{l}\text { Sepatu Bata } \\
\text { Tbk. }\end{array}$ & 0,48 & 0,72 & 0,81 & 0,45 & 0,41 & 0,57 \\
\hline 4 & $\begin{array}{l}\text { Multi } \\
\text { Bintang } \\
\text { Indonesia } \\
\text { Tbk. }\end{array}$ & 2,49 & 0,80 & 3,03 & 1,74 & 3,56 & 2,32 \\
\hline 5 & $\begin{array}{l}\text { Selamat } \\
\text { Sempurna } \\
\text { Tbk. }\end{array}$ & 0,76 & 0,69 & 0,53 & 0,54 & 0,38 & 0,58 \\
\hline 6 & $\begin{array}{l}\text { Surya Toto } \\
\text { Indonesia } \\
\text { Tbk. }\end{array}$ & 0,70 & 0,69 & 0,65 & 0,64 & 0,55 & 0,65 \\
\hline
\end{tabular}

Sumber : Data yang diolah dari Laporan Keuangan Publikasi di BEI

Pada tabel 6 menunjukkan dimana perusahaan Astra International Tbk. untuk nilai rasio DER pada tahun 2012 dan 2013 berada di atas 1,00 yaitu sebesar 1,03 dan 1,02. Selanjutnya untuk nilai rasio DER yang berada di atas 1,00 yaitu Multi Bintang Indonesia Tbk. pada tahun 2012, 2014, 2015, 2016 sebesar 2,49; 
3,$03 ; 1,74$; dan 3,56 .

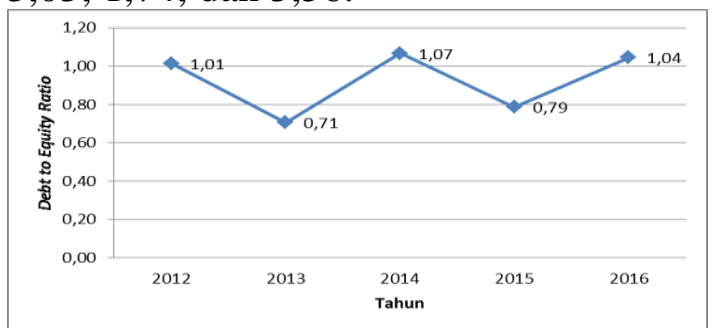

Sumber : Data yang diolah dari Laporan Keuangan Publikasi di BEI

Gambar 5. Perkembangan Rata-rata Debt to Equity Ratio pada Perusahaan

Sektor Manufaktur di Bursa Efek Indonesia Periode 2012-2016

Pada tabel 6 menunjukkan pada tahun 2013 dan tahun 2015 perkembangan rata-rata Debt to Equity Ratio yaitu 0,71 dan 0,79 menandakan saham perusahaan lebih besar dari pinjaman perusahaan dikarenakan berada di bawah angka 1,00. Sedangkan sebaliknya pada tahun 2012, 2014, dan 2016 berada di atas angka 1,00 yaitu sebesar 1,$01 ; 1,07$; dan 1,04 .

\section{Uji Normalitas}

Hasil pengujian pada Gambar menunjukan besarnya nilai probabilitas sebesar 0,125647 dimana nilai probabilitas lebih besar dari tingkat signifikansi yang telah ditetapkan sebelumnya yaitu 0,05 , maka model yang dibuat telah berdistribusi normal.

\section{Uji Multikolinearitas}

\section{Tabel 7}

Hasil Uji Multikolinearitas pada Perusahaan Sektor Manufaktur di Bursa

\begin{tabular}{cccc} 
Efek Indonesia Periode 2013-2016 \\
\hline Variable & $\begin{array}{c}\text { Coefficient } \\
\text { Variance }\end{array}$ & $\begin{array}{c}\text { Uncentered } \\
\text { VIF }\end{array}$ & $\begin{array}{c}\text { Centered } \\
\text { VIF }\end{array}$ \\
\hline C & 0.014128 & 3.107550 & NA \\
ROA & 0.514276 & 4.618550 & 2.085944 \\
AG & 0.402490 & 3.235155 & 1.704163 \\
DER & 0.009834 & 3.083592 & 1.328244 \\
\hline
\end{tabular}

Sumber : Output Eviews 9
Berdasarkan diperoleh nilai VIF semua variabel lebih kecil dari 10 dan nilai tolerance lebih besar dari 0,1 pada masing-masing variabel independent yaitu untuk $R O A$ yaitu sebesar 2,085944; $A G$ yaitu sebesar 1,704163 dan DER yaitu sebesar 1,328244. Sehingga dalam uji analisis ini dapat dinyatakan tidak terjadi multikolinearitas.

\section{Uji Heteroskedastisitas}

\section{Tabel 8}

Hasil Uji Heteroskedastisitas pada Perusahaan Sektor Manufaktur di Bursa Efek Indonesia Periode 2013-2016 Heteroskedasticily Test: White

\begin{tabular}{|c|c|c|}
\hline F-statisic & 0.674879 Prob. F(3,20) & 0.5775 \\
\hline Obs* $R$-squared & 2.206224 Prob.Chi-Square(3) & 0.5307 \\
\hline Scaled explained SS & 2.604511 Prob.Chi-Square(3) & 0.4567 \\
\hline
\end{tabular}

Sumber : Output Eviews9

Berdasarkan Tabel 8 diperoleh hasil nilai probabilitas chi-square sebesar 0,5307. Hal tersebut menunjukan probabilitas chi-square > 0,05 berarti model regresi tidak mengandung gejala heteroskedastisitas.

\section{Uji Autokorelasi}

\section{Tabel 9}

Hasil Uji Autokolerasi pada Perusahaan Sektor Manufaktur di Bursa Efek Indonesia Periode 2013-2016 Breusch-Godfrey Serial Correlation LMTest:

\begin{tabular}{llll}
\hline \hline F-statistic & 2.452356 & Prob. F(3,17) & 0.0986 \\
Obs ${ }^{*}$ R-squared & 7.249216 & Prob.Chi-Square(3) & 0.0644 \\
\hline \hline
\end{tabular}

Sumber : Output Eviews 9

Berdasarkan pada Tabel 9 terlihat besarnya nilai prob $>$ F sebesar 0,0986 dimana nilai probabilitas lebih besar dari tingkat signifikansi yang 
telah ditetapkan sebelumnya yaitu 0,05 . Apabila probabilitas $F>0,05$ maka model regresi tidak terdapat autokorelasi. Dari tabel 9 menunjukkan bahwa nilai probabilitas cross section $\mathrm{F}$ sebesar $0,0034<0,05$. Ini berarti Ho ditolakdan $\mathrm{Ha}$ diterima sehingga estimasi model regresi menggunakan fixed effect model.

\section{Tabel 10}

Hasil Analsis Uji Chow-test pada Perusahaan Sektor Manufaktur di Bursa

Efek Indonesia Periode 2013-2016

Redundant Fixed Effects Tests

Equation: Untitled

Testcross-section fixed effects

\begin{tabular}{lrrr}
\hline \hline Effects Test & Statistic & d.f. & Prob. \\
\hline \hline & 5.840064 & $(5,15)$ & 0.0034 \\
Cross-section F & 5 & 0.0001 \\
Cross-section Chi-square & 25.936363 & & \\
\hline \hline
\end{tabular}

Sumber : Output Eviews 9

\section{Uji Hausman}

Berdasarkan Tabel 10 diperoleh nilai probabilitas cross section random sebesar $0,0000<0,05$. Ini berarti $\mathrm{Ho}$ ditolak dan $\mathrm{Ha}$ diterima sehingga model yang digunakan adalah fixed effect model.

Tabel 11

Hasil Analsis Uji Hausman pada Perusahaan Sektor Manufaktur di Bursa

Efek Indonesia Periode 2013-2016

Correlated Random Effects - Hausman Test Equation: Untitled

Test cross-section random effects

\begin{tabular}{lrrr}
\hline \hline Test Summary & Chi-Sq. Statistic & Chi-Sq. d.f. & Prob. \\
\hline \hline Cross-section random & 25.355737 & 3 & 0.0000 \\
\hline \hline
\end{tabular}

Sumber : Output Eviews 9

\section{Analisis Regresi Panel}

Tabel 12

Hasil Analsis Regresi Data Panel mengunakan metode Fixed Effect pada
Perusahaan Sektor Manufaktur di Bursa

Efek Indonesia Periode 2013-2016

\begin{tabular}{|c|c|c|c|c|}
\hline Variable & Coefficient & Std. Error & t-Statistic & Prob. \\
\hline ROA & -3.600745 & 1.053867 & -3.416698 & 0.0038 \\
\hline$A G$ & 1.111801 & 0.535095 & 2.077764 & 0.0553 \\
\hline DER & -0.633358 & 0.124253 & .5 .097313 & 0.0001 \\
\hline c & 1.449205 & 0.207042 & 6.999564 & 0.0000 \\
\hline \multicolumn{5}{|c|}{ Effects Specification } \\
\hline \multicolumn{5}{|c|}{ Cross-sectionfixed (dummy variables) } \\
\hline R-squared & 0.705901 & \multicolumn{2}{|l|}{ Mean dependentvar } & 0.486354 \\
\hline Adjusted R-squared & 0.549049 & \multicolumn{2}{|l|}{ S.D. dependentvar } & 0.330636 \\
\hline S.E. of regression & 0.222031 & \multicolumn{2}{|l|}{ Akaike info criterion } & 0.108000 \\
\hline Sum squared resid & 0.739469 & \multicolumn{2}{|l|}{ Schwar criterion } & 0.549770 \\
\hline Log likelihood & 7.703997 & \multicolumn{2}{|l|}{ Hannan-Quinn criter. } & 0.225202 \\
\hline F-statistic & 4.500411 & \multicolumn{2}{|l|}{ Durbin-Watson stat } & 2.001132 \\
\hline $\operatorname{Prob}(\mathbf{F}-$ statistic) & 0.049530 & & & \\
\hline
\end{tabular}

Sumber : Output Eviews 9

Untuk uji t statistik untuk ROA dan DER berpengaruh terhadap DPR, hal tersebut dikarenakan hasil uji $t$ menunjukkan uji prob thit $<0,05$ dengan nilai 0,0038 untuk Return On Asset, dan 0,0001 untuk Debt to Equity Ratio. Sedangkan, variabel AG tidak berpengaruh terhadap DPR, hal tersebut dikarenakan hasil uji $\mathrm{t}$ menunjukkan uji prob thit $>0,05$ dengan nilai 0,0553. Untuk uji $F$ statistic pada tabel nilai prob(Fstatistic) dengan nilai 0,049530, dimana jika prob $F_{\text {hit }}<0,05$ maka $\mathrm{Ha}$ diterima. Artinya terdapat pengaruh yang signifikan secara simultan dari ROA, AG, dan DER terhadap DPR.

Nilai adjusted R-squared yaitu sebesar 0,549049 atau 54,91\%. Dimana variabel bebas (ROA, AG, dan DER) berpengaruh sebesar 54,91\% sedangkan sisanya sebesar $45,09 \%$ dipengaruhi oleh variabel-variabel lain yang berasal dari luar model penelitian.

Pengaruh Return On Asset, Asset Growth, dan Debt to Equity Ratio 


\section{terhadap Devidend Payout Ratio}

Berdasarkan Tabel 12 dengan model fixed effect telah diketahui bahwa nilai probabilitas $f$ hitung pada ketiga variabel independen yaitu Return On Asset, Asset Growth, dan Debt to Equity Ratio sebesar 0,049530 yang menunjukkan bahwa prob $f$ hitung $<0,05$. Maka dapat dilihat bahwa Return On Asset, Asset Growth, dan Debt to Equity Ratio secara simultan berpengaruh pada variabel Devidend Payout Ratio. Dan nilai Rsquared adalah sebesar 0,549049. Hal ini menunjukkan bahwa kemampuan variabel-variabel Return On Asset, Asset Growth, dan Debt to Equity Ratio secara simultan berpengaruh pada variabel Devidend Payout Ratio sebesar $54,91 \%$, sedangkan sisanya sebesar 45,09\% dipengaruhi oleh variabel-variabel lain yang berasal dari luar model penelitian.

\section{E. KESIMPULAN DAN SARAN}

\section{KESIMPULAN}

Berdasarkan pembahasan hasil pengujian hipotesis yang telah dijelaskan dalam halaman di atas, maka penelitian ini hasilnya dapat disimpulkan bahwa Return On Asset, Asset Growth, dan Debt to Equity Ratio berpengaruh secara simultan terhadap Dividend Payout Ratio pada perusahaan sektor manufaktur yang terdaftar di Bursa Efek Indonesia. Hal ini ditunjukan dengan nilai prob $\mathrm{f}$ hitung yaitu $0,049530<0,05$ dimana $\mathrm{H}_{4}$ diterima dengan koefisien determinan sebesar 0,5491 yang menunjukkan berpengaruh sebesar $54,91 \%$.

\section{SARAN}

Hasil analisis dan pembahasan, variabel yang berpengaruh dalam penelitian ini seperti laba perusahaan, pengelolaan modal dan hutang perusahaan sebaiknya dapat digunakan oleh investor sebagai pilihan untuk membeli atau menjual saham sehingga dapat memperoleh pembayaran deviden sesuai harapan yang akan diberikan oleh perusahaan.

\section{DAFTAR PUSTAKA}

Abdul Halim, dan Mamduh M. Hanafi. 2009. Analisis Laporan Keuangan. Edisi 4.Yogyakarta : UPP STIM YKPN.

Al-Malkawi, Husam-Aldin Nizar. 2008. Factors Influencing Corporate Dividend Decision: Evidence from Jordanian Panel Data. International Journal of Business 13(2).

Agus Sartono. 2009. Manajemen Keuangan Teori dan Aplikasi. Edisi 4. Yogyakarta: BPFE.

Aries Heru Prasetyo. 2011. Manajemen Keuangan bagi Manajer Non Keuangan. Jakarta : PPM.

Bambang Riyanto. 2008. Dasar-dasar Pembelanjaan Perusahaan. Yogyakarta : Penerbit BPFE.

Darmadji dan Fakhruddin. 2011. Pasar Modal Indonesia. Edisi Ketiga. Jakarta : Salemba Empat.

Darsono dan Ashari.2010. Pedoman Praktis Memahami Laporan Keuangan (Tips Bagi Investor, Direksi, dan Pemegang Saham). Yogyakarta : Penerbit Andi.

Dedy Natanael Baramuli. 2016. Pengaruh Likuiditas Dan Profitabilitas Terhadap Devidend Payout Ratio Pada Top Bank Di Indonesia (BRI, Bank Mandiri, BNI dan BCA). Jurnal Berkala Ilmiah Efisiensi. Volume 16 No. 03.

Dwidarnita Parera. 2016. Pengaruh Return On Asset (ROA), Asset Growth (AG) Dan Debt To Equity Ratio (DER) Terhadap Dividend Payout Ratio (DPR). 
Jurnal EMBA. Vol.4 No.2 Juni 2016, Hal. 538-548.

Enekwe, Nweze, and Agu. 2015. Factors Affecting The Firm Dividend Policy: An Empirical Evidence From Textile Sector Of Pakistan. Europan Journal of Accounting, Auditing and Finance Research. Vol.3, No.11, pp.40-59.

Fama, E.F. dan K.R. French. 2001. The Cross Section Of Expected Stock Returns. Journal Of Finance. 47:427-465.

Handono Mardiyanto. 2009. Intisari Manajemen Keuangan. Jakarta: Grasindo.

Hery. 2015. Analisis Laporan Keuangan. Yogyakarta: CAPS.

Husein, Umar. 2011. Metode Penelitian Untuk Skripsi dan Tesis Bisnis Edisi 11. Jakarta: PT Raja Grafindo Persada.

H.M.N Purwosutjipto. 2003. Pengertian Pokok Hukum Dagang Indonesia Jilid 6. Jakarta : Djambatan.

Ikechukwu, Agu Charles, 2015. The Effect Of Dividend Payout On Performance Evaluation: Evidence Of Quoted Cement Companies In Nigeria. European Journal of Accounting, Auditing and Finance Research.

Imam Ghozali. 2009. Aplikasi Analisis Multivariate Dengan Program SPSS, Edisi Keempat, Semarang : Universitas Diponegoro.

Imran, Kashif. 2011. Determinants of Dividend Payout Policy: A Case of Pakistan Engineering Sector. The Romanian Economic Journal, 14 (41), pp: 47-60

Irham fahmi. 2011. Analisis Laporan Keuangan. Bandung : Alfabeta.

Kasmir. 2014. Analisis Laporan Keuangan. Jakarta: PT Rajawali Persada.
Kasmir. 2012. Analisis Laporan Keuangan. Jakarta: PT Rajawali Persada.

Kurniawan E.R dkk, 2016, "Pengaruh Cash Position, Debt Equity Ratio, Return On Asset, Current Ratio, Firm Size, Price Earning Ratio, Dan Total Assets Turn Over Terhadap Deviden Payout Ratio", Journal Of Accounting, Volume 2 No.2.

Ladzi Safroni. 2012. Manajemen dan Reformasi Pelayanan Publik dalam KonteksBirokrasi Indonesia. Yogyakarta: Aditya Media Publishing.

Munawir. 2001. Akuntansi Keuangan dan Manajemen. Edisi Pertama. Yogyakarta : BPFE.

Rahayuningtyas, Septi. Suhadak dan Siti Ragil Handayani. 2014.Pengaruh Rasio- Rasio Keuangan Terhadap Dividend Payout Ratio (DPR) (Studi Pada Perusahaan Yang Listing Di BEI Tahun 2009-2011). Jurnal Akuntansi Bisnis. Volume 7.Nomor 2.

Rembulan, M. Nadratuzzzaman, Syafaat. 2016. Analysis Of Factors That Impact Dividend Payout Ratio On Listed Companies At Jakarta Islamic Index. International Journal of Academic Research in Accounting, Finance and Management Sciences. Vol. 6 No.2, April 2016, pp. 87-97

Rusdin. 2006. Pasar Modal. Bandung : Alfabeta.

Sleihat, Nimer, 2013. The Impact of Profitability on Obtaining Debt through the Financial Leverage: Comparative Study among Industrial Sectors in Jordan. Interdisciplinary Journal Of Contemporary Research In Business. 
Sugiyono. 2006. Statistika Untuk Penelitian. Cetakan Ketujuh. Bandung: CV. Alfabeta.

Sugiyono. 2012.Metode Penelitian Bisnis. Bandung : Alfabeta.

Sugiyono. 2013. Metode Penelitian Kuantitatif Kualitatif dan R \& D. Bandung : Alfabeta.

Warner R Murhadi. 2013. Analisis Laporan Keuangan, Proyeksi dan Valuasi Saham. Jakarta : Salemba Empat.

Winda Qoirotun Jannah, Sasi Agustin. 2014. Faktor-Faktor Yang Mempengaruhi Dividend Payout Ratio Pada Perusahaan Industri Barang Konsumsi. Jurnal Ilmu \& Riset Manajemen Vol. 3 No. 4. Surabaya : Sekolah Tinggi Ilmu Ekonomi Indonesia (STIESIA).

Umi Narimawati. 2010. Penulisan Karya Ilmiah. Jakarta: Penerbit Genesis. 